УДК 821.161.2-32.09Маковей

Стрюк Лариса,

кандидат філологічних наук, професор, професор кафедри української та світової літератур Криворізький державний педагогічний університет

\title{
ПОЕТИКА ПОЗАЗБІРКОВИХ СОЦІАЛНО-ПОБУТОВИХ ОПОВІДАНЬ ОСИПА МАКОВЕЯ
}

У статті розглянуто провідні ознаки поетики позазбіркових сочіально-побутових оповідань Осипа Маковея. Дослідження творів показало, що в основу сюжету покладено один випадок з життя селян Західної України кіния XIX - початку XX століть, який дає можливість автору порушити низку актуальних проблем доби. Письменник з метою вираження своєї позиції вдається до багатої палітри художніх засобів, прийомів, щь виразно характеризують його творчу манеру.

Ключові слова: драматичне нагнітання, іронія, контраст, проблема, паралель, художня деталь, метафора, порівняння.

\section{Poetics of non- collection social stories by Osip Makovey.}

The article considers the main poetics features of Osip Makovey's outside the collection social stories. The study of the works showed that the plot based on one case from the life of Western Ukraine villagers at the end of the XIX and early XX centuries, which enables the author to raise a number of urgent problems of the era. The writer uses a rich palette of artistic means, techniques that visually characterize his creative manner in order to express his position.

Keywords: drama aggravation, irony, contrast, problem, parallel, artistic detail, metaphor, comparison.

Відоме твердження, що кожен письменник син своєї епохи, тому у його творчості так чи інакше постає ціла система точок зору на явища тогочасної дійсності, які пов'язані 3 його світоглядом i очікуваннями тих верств суспільства, які він представляє, і до яких звернене його художнє слово. Як 
зазначав Ф. Погребенник, Осип Маковей - автор соціально-побутових творів «схоплених з потоку життя»[Погребенник 1990 : 5]. Тому через його твори проглядається атмосфера суспільного життя Західної України межі XIX-XX століть. Він намагався «задовольнити потреби часу» [Погребенник 1990 : 5], звернувши увагу у своїх творах на моральні і соціальні вади, властиві тогочасному суспільству, залишивши таким чином нащадкам «чимало важливих свідчень» [Погребенник 1990 : 5]. Його твори несуть у собі інформацію і про самого автора як творчу особистість зі своїм поглядом на життя, сформованим життєвим досвідом журналіста, який черпав враження 3 реальної дійсності і намагався бути якомога правдивим та об’єктивним у висловленні власних суджень, вибудовуванні сюжетів, розстановці смислових акцентів.

Твори Осипа Маковея високо поціновували його сучасники: I. Франко, M. Коцюбинський, . Кобилянська, М. Грушевський та iнші [Засенко 1968; Історія української літератури 2005; Мельничук 1956; Погребенник 1960]. І. Дзюба вважав, що він належить до зірок «першої величини, яких історія, коли приходить на те час, називає іменням класиків» [Дзюба 1998 : 14]. В. І. Кузьменко називає О. Маковея серед плеяди потужних талантів початку XX століття [Кузьменко 2013:10]. I О. Засенко, i Ю. Мельничук, і Ф. Погребеник, зробивши огляд творів письменника, звернули увагу на їх тематику, проблематику, жанрове багатство, але грунтовно поетику творів письменника не вивчали, хоча вказували на їх зв'язок 3 фольклором. Саме тому у сучасних умовах проблема вивчення поетики прозових творів Осипа Маковея залишається актуальною.

Мета статті - дослідити особливості поетики позазбіркових соціальнопобутових оповідань письменника.

Досліджуючи позазбіркові твори Осипа Маковея, яким найменше приділялося уваги вітчизняним літературознавством, ми помітили, що провідне місце займають твори про бідування українського народу за часів панування польсько-шляхетських та австро-угорських поневолювачів. Злиденне існування 
однієї селянської родини в оповіданні «Заробок на свята» письменник окреслює метафорою: «B хату Сенька Польового загостила нужда» [Маковей 1990 : 353]. Ефект драматичного нагнітання посилює порівняння: «Посипалось на Сенька нещзастя за нещзастям, мов 3 платка» [Маковей 1990 : 353]. I перерахування низки бід утримують цей ефект: помер його хлопчик-одинак; він позбувся шматка землі, щоб відбути похорон; влітку згинула худоба; «град потовк, помервив збіжжя - не було щуо й збирати!..» [Маковей 1990 : 354]. Автор подає головного персонажа як людину з високим почуттям гідності, він ніколи не жалівся на скрутний стан, як міг заробляв, не опускав рук, прагнув, щоб ніхто не знав, що його спіткала нужда. Але в той же час його чекало «сумне різдво» [Маковей 1990 : 354]. Змітав тріски, щоб було чим затопити піч, зварити вечерю, бо за цілий день «він нічого не мав у ротіхоть до причастя йди!» [Маковей 1990 : 354]. Автор вдається до гіркої іронії, вказуючи на голодування селянина. Саме це змусило Сенька згодитись на полювання на зайця 3 паничем, оскільки ще у війську навчився добре стріляти. Йому обіцяли «ринського». Його дружина зраділа, бо «свята йшли, а вона не мала щьо й в рот вложити» [Маковей 1990 : 355]. Її радість автор підкреслює порівнянням «мовби їй хто сотку обіцяв» [Маковей 1990 : 355], яке має іронічне забарвлення. У внутрішню мову персонажа письменник вводить спогади про службу у війську, коли теж «не знав гаразду» [Маковей 1990 : 355], але «все легше було жити», бо «не журився бодай їдюю» [Маковей 1990 : 355]; про мрії з дружиною доробитися «щее ліпшого гаразду $і$ при дітях щуасливо проведуть свої літа» [Маковей 1990 : 355]. Ці думки про щасливу родину контрастують 3 тією ситуацією, яка лягла в основу сюжету і яка гостро ставить проблему руйнування селянської родини, а також проблему безкарності панства, відсутність сумління, немилосердя, бездушність у ставленні до селян. Панич, встреливши випадково Сенька, спочатку втішився, що «ніхто сего не бачив!» [Маковей 1990 : 357], потім «почав утікати домів» і врешті-решт виправдовував себе: «...Чи я сему винен? Чи я нарочно стріляв в него? Ніхто мене не видів. А буде слідство, то покаже сь, щуо то проста стрілецька 
пригода...» [Маковей 1990 : 357]. Автор, зображуючи полювання, акцентує на хижому азарті панича i на милосерді селянина, який змушений через тяжку нужду вбивати звірів. Звертає на себе увагу внутрішня мова Сенька, який, ніби передчуваючи власну смерть, проводить подумки паралель: «Жаль мені справдi сернюка: жив собі, мабуть, спокійно, аж ось єму $і$ смерть прийшла, та ще й несподівана. Так то і чоловікові наугад буває; ні дня, ні години не знаєш» [Маковей 1990 : 356]. Ці рядки автор використав як установку на сприйняття трагіко-драматичних подій у творі: загибель Сенька, а потім і його дружини. Своєрідну установку автор робить і за допомогою художньої деталі: «Панич стрілив... 3 дерева зірвався наполоханий крук $i$ закрякав...» [Маковей 1990 : 356]. За народним повір'ям крук є символом смерті, а його крик віщує загибель чи лихо.

Характеризуючи Марину, автор називає іï змученою, зображує у хвилюванні за чоловіком. Вона чекає, шукає, розпитує, іiі тривожить питання: «Де він дівся?» [Маковей 1990 : 358]. У iï внутрішню мову автор вводить порівняння народнопоетичного походження: «Сенька нема, пропав, мов камінь $y$ водi» [Маковей 1990 : 358]. Письменник надзвичайно точно передає психологічний стан жінки, схвильованої раптовим зникненням чоловіка, називає місця можливого його перебування, а коли до святого вечора залишається дві-три години, іiі охоплює тяжке передчуття: «Може, там єму щзось сталося? На ту гадку аж сериче єї щзось імило» [Маковей 1990 : 358 ]. Вона відважилась піти шукати чоловіка на місці його полювання, але там було видно «лище сліди звірів... на снігу» [Маковей 1990 : 358]. Згорьована жінка, як зазначає автор, «вголос заплакала. - Боже мій! Де ж він подівся?» [Маковей 1990 : 358]. Письменник метафорою передає психологічний стан жінки, яка побачила на снігу людські сліди і кров: «B ній аж єї власна кров застигла» [Маковей 1990 : 358]. Побачивши, що «за корчами лежить Сенько» [Маковей 1990 : 358], вона скрикнула: «Господи!..» $і$ повалилась на землю» [Маковей 1990 : 358]. Опритомнівши, жінка переконалась, що він неживий, і це стало для неї смертельним ударом: «То він вже неживий! - скрикнула жінка в 
нестямі. - Отже заробив ти на свята! Люди добрі, рятуйте!» - заголосила Марина і вдруге повалилася на землю...» [Маковей 1990 : 358]. Останні слова жінки прозвучали як звинувачення суспільним умовам, коли заробіток коштує людині життя. На приреченості людини 3 демократичного середовища акцентує фраза «Ніхто єї не чув, ніхто не прийшов на поміч, лише в лісі глухо та сумно зашуміло» [Маковей 1990 : 358]. На драматизмі ситуації наголошують риторичні конструкції.

Трагіко-драматична тональність твору підкреслюється контрастом між загальним і окремим: «Люди сіли до вечері. Ціле село повеселішало, колядники співали, з вікон у кождій хаті било ясне світло, лише одну Сенькову хату залягла темрява» [Маковей 1990 : 358]. Зміст цих слів передбачає антитези: світло - темрява, свято - сум, життя - смерть. Оповідання завершують рядки: «На Стефана поховали Сенька і Марину в одній могилі. ...В пустій їх хаті плакали гірко старий Копач та єго жінка» [Маковей 1990 : 359]. Ці слова спонукають до роздумів над трагічною долею персонажів, причинами загибелі молодої родини, проблемами ранньої дитячої смерті, незахищеної старості, голоду, холоду, безгрошів'я, приреченості на страждання людей 3 демократичних кіл.

Гірке життя гуцулів зобразив О. Маковей у оповіданні «Поза правом», головним персонажем якого постає гуцул Юра Боднарюк. Була у нього, як зазначає автор, «хата внизу, над самим Черемомем, був $і$ садок, $і$ кусень поля» [Маковей 1990 : 404]. Але його ошукав Янкель і все забрав «за довги, за лихву, судові кошти i m. n.» [Маковей 1990 : 404]. Тому Юра змушений був іти у гори. Автор зазначає: «Юра пішов у верхи, мов медвідь, $і$ там бездітним вдівием доживає віку» [Маковей 1990 : 404]. Порівняння Юри з ведмедем підкреслює втечу його від суспільства, в якому панує визиск і несправедливість. Автор наголошує, що «там під хмарами він почуває себе свобідним» [Маковей 1990 : 404]. Це вказує на проблему відчуженості людини від суспільства. Письменник іронічно зазначає, що усамітнений Юра «зовсім не хоче знати того, щьо земля вже давно поділена поміж людей, а високі гори з 
лісами вже не свобідні» [Маковей 1990 : 404]. Він іронічно зазначає, що Юра «думає зовсім по-старосвітськи» [Маковей 1990 : 404], вважаючи, що бог створив чудові ліси, а не пани, тому іде «y недалекий ліс православного релігійного фонду» [Маковей 1990 : 405] і рубає «гарну смерічку, як свою» [Маковей 1990 : 405], щоб полагодити хату. Вражає опис його житла: «Хатина на стромині, перегнила, похилена, коли б не каміння на плоскій криші, то добрий вітер здув би єї у яр, як суху галузку» [Маковей 1990 : 404]. Порівняння хатини з сухою галузкою підкреслює іï вбогість, мізерність, ветхість. Крім того, кілька раз у тексті використовується повтор епітетів, які характеризують ії як «самотню», «гнилу» [Маковей 1990 : 406]. Автор акцентує на тому, що «ні для кого не мала вона ціни, тільки для Юри» [Маковей 1990 : 406]. Використовує письменник у тексті твору прийом парадоксу, зосередившись на штрафі за зрубану смерічку. Спочатку «засудили єго на одну крону і 32 сотики кари», «не минула ще цे зима, а вже кошти зросли на 67 к(рон) 38 сот(их)» [Маковей 1990 : 405], а восени «він винен дирекиї̈ фонду смерічку і все те, щцо за смерічку виросло... Через єго недбалість і впертість дирекиія фонду має вже втрати коштів на 276 к(орон)» [Маковей 1990 : 406]. Автор наголошує, що у праві влада подбала про себе, про своїх представників, вона врахувала все, що стосується можновладців, але не врахувала рівень життя і можливості найбідніших верств народу, тому вони залишилися поза правом. О. Маковей іронічно зазначив: «Ті, щуо писали закони, не знали про гуцула на самітнім верху між лісами. Він стоїть поза правом» [Маковей 1990 : 406]. На цій ключовій думці акцентується назвою твору та зауваженням, що світові байдуже, чи $є$ такі, як Юра, а також і Юрі байдуже, як живе світ. Це підкреслює проблему відчуженості. Прозаїк акцентує на безправ’ї людини, ії життя перетворюється у пекло, коли вона стикається з суспільством, в якому панують антигуманні закони. Ця думка посилюється, стає ще виразнішою, коли подається психологічна реакція Юри на штраф і покарання за смерічку: «Юра подивився,.. мовчки сів собі на порозі і закурив люльку» [Маковей 1990 : 405], «одсидів дві доби в арешті, ...і пішов у гори, на свій самотній верх», «возний... не забрав 
нічого, бо не було щуо. Юра курив... спокійно, як звичайно...» [Маковей 1990 : 406], «Юра слухав того, як казки, дивувався трохи, але нарешті відповів спокійно: - Звідки взяти? - I з тим пішов собі знову на свій

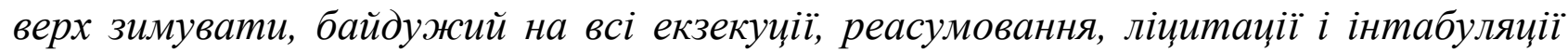
комісії, едикти...»[Маковей 1990 : 406]. Завдяки цим акцентам автор створює складну психологічну ситуацію, коли персонаж спокійний, а читач обурений 3 того, у яку безвихідну ситуацію може потрапити людина 3 демократичних кіл. До того ж у творі наголошується на тому, що природні ресурси повинні належати всім, а не лише панству.

Захищає права людини 3 народу письменник і в оповіданні «3 одного джерела», у центрі якого персонаж - «вічний» студент прав $і$ канцелярійний помічник адвоката» [Маковей 1990 : 441] Іван Петришин, який і постає свідком антигуманного ставлення до селян «попа-деруна» отця Ріпака. Він також чув його розмову з селянином про похорон дитини, як той торгувався про ціну служби. На думку Петришина, «се ж прекрасна тема для допису! Tуm сам священик знає $і$ каже, щуо хлопа ліщуитують, $i$ проте дере з нього за марницю три ринські!.. Не штука, - думав він собі, - грати ролю патріота $і$ давати на будову бурси дві тисячі, як изе отецьь Ріпак недавно зробив, коли обдирає темних селян отак, як Будного» [Маковей 1990 : 442]. В уста головного персонажа письменник вкладає звинувачення у немилосердному ставленні до селян священика.

Крім того, Будний розповідає Петришину про своє лихо з позикою. Він у Абрумка позичив «30 золотих ринських» [Маковей 1990 : 443], коли померла його перша дружина, потім ще 30 3/p, коли одружувався вдруге, i 10 3/p на купівлю підсвинка, щоб розрахуватися з боргами, але підсвинок загинув, «мало щุo зібрав з поля. Проценти росли...» [Маковей 1990 : 443]. I тепер він повинен заплатити удвічі більше, «півтори сотки довгу» [Маковей 1990 : 443]. Суд не підтримав селянина i той обурився: «Чи mо nо правдi diєmься?» [Маковей 1990 : 443]. Він вирішив писати «просьбу до найяснішого пана» [Маковей 1990 : 443], щоб домогтися справедливості. Петришин пожалів 
селянина, порадивши не витрачати гроші на цей процес, бо він справи не виграє, тому «шкода кожного сотика» [Маковей 1990 : 444]. Та селянин йому не повірив, звернувся до адвоката, який за послугу вимагав «n'ятнадиять срібних» [Маковей 1990 : 444], бо «до найяснішого пана не можна як-будь писати» [Маковей 1990 : 444]. I селянин, віддавши гроші, «вдоволений вийиов 3 канцелярії» [Маковей 1990 : 444], бо мав надію, що знайде захист і підтримку. На репліку Петришина, що ця справа програна, адвокат різко сказав: «Не відганяйте мені клієнтів» [Маковей 1990 : 444]. Петришин 3 певним докором нагадав адвокату, що той «знаний народолюбецьь-nатріот» [Маковей 1990 : 444]. На що адвокат відповів, що його першим обов’язком «сповняти волю «сторони» $i$ з того жити» [Маковей 1990 : 444] і порадив своєму помічнику, що якщо той теж не буде так робити, то «не буде мати ні маєтку, ні родини, ні спокою, ні поважання $y$ «сторін», товаришів $i$ суспільності...» [Маковей 1990 : 444]. Крім того, адвокат зауважив, що жоден селянин йому не дорікав, «хоч справу програв $i$ y Bidнi» [Маковей 1990 : 444]. Головний персонаж висловлює думку і власне автора, що і священик, і адвокат черпають «з того самого джерела» [Маковей 1990 : 445], тільки адвокат вп’ятеро більше, ніж священик «і за меншу пращ̧ю» [Маковей 1990 : 444], тому Петришин порвав свою викривальну статтю про священика, написану до видання «Громадський голос».

Сюжет твору побудований за принципом нанизування епізодів 3 життя одного селянина, але це дозволило автору викрити лже-патріотів, які лише на словах дбають про свій народ, а на ділі паразитують, живуть 3 нього, ставляться зневажливо-байдуже, виявляючи немилосердя. Людина 3 демократичних кіл залишається ошуканою. Тому в оповіданні «Добрий інтерес» автор вкладає в уста епічного «я» низку риторичних запитань, які характеризують епоху, ставлення до народу, його долі: «Але хто-то довів наших людей до того, щүо вони не розуміють свого інтересу? Хто-то їх учив $і$ як учив дотепер?.. Як щукати причин сеї темноти, то є їх більще, та й не всі по нашім боціџ» 
[Маковей 1990 : 404]. Ці рядки мають публіцистичний характер і окреслюють авторський погляд на головні проблеми доби.

На основі проведеного дослідження можемо стверджувати, що в основу сюжету соціально-побутових оповідань О. Маковея покладено окремі випадки 3 життя західноукраїнських селян, які дають можливість створити яскраву картину бідування народу через антигуманну суспільну систему, несправедливе судочинство, здирництво, немилосердя, зневагу до простої людини, що властиві панівним колам. Для оповідань характерна драматична та трагікодраматична тональність оповіді 3 домішками іронії, як засобу викриття та вираження позиції автора на зображувані соціальні явища, а також публіцистичних вкраплень, що спонукають задуматись над важливими морально-етичними та суспільними проблемами доби. Оповідач у творах свідок або учасник подій. Голос власне автора проступає у авторських зауваженнях, відступах, мовних партіях персонажів та публіцистичних вкрапленнях. Творчу манеру письменника характеризує багата художня палітра, що має важливе виражально-зображальне значення: метафори («загостила нужда», «посипалось нещ̧астя за нещзастям», «кров застигла», «хату залягла темрява» та інші), епітети («сумне різдво», «наполоханий крук», «в пустій хаті», «високі гори з лісами вже не свобідні», «хатина перегнила, похилена», «самотня» та інші), порівняння («посипались нещуастя, мов 3 платка», Марина зраділа, «мовби їй хто сотку обічяяв», «пропав, мов камінь у воді», «пішов у верхи, мов медвідь» та інші), народні примовки («купованим хлібом не наїсися», «нічого не мав у роті - хоть до причастя йди!» та інші). Автор використовує також ретроспективні, екзистенційні, публіцистичні вкраплення, риторичні конструкції, художні деталі, образи-символи, прийоми контрасту, нанизування, драматичного нагнітання, віщування, художньої установки, паралелі, іронії, психологічні портрети, мовну характеристику та інше.

У центрі уваги автора проблема розорення селянства, його напівголодне життя, соціальна незахищеність, безперспективність існування, бідування, 
приреченість, рання смертність; проблема несправедливого судочинства, ошукування селян; проблема здирництва i абсурдних штрафів; проблема руйнування селянської родини; проблема безкарності панства, їх немилосердя по відношенню до селян. Крім того, прозаїк гостро ставить проблему відчуженості «маленької людини» від світу і ворожість та немилосердя світу по відношенню до неї, бо вона безправна, оскільки залишилась «поза правом». Як бачимо, позазбіркові соціально-побутові оповідання Осипа Маковея з життя селянства західноукраїнських земель характеризує багатопроблемність. Автор надзвичайно точно передає колорит епохи, захищає, як прогресивний письменник, інтереси людей 3 демократичних кіл. Дослідження поетики його творів має широку літературознавчу перспективу, оскільки наочно представляє особливості творчої манери письменника, його художні здобутки, традиції i новаторство, мистецьку самобутність.

\section{БІБЛІОГРАФІЯ}

Дзюба 1998 - Дзюба I. Літературно-мистецьке життя / Іван Дзюба // Історія української літератури ХХ століття : У 2 кн. - Кн. 1 : Перша половина ХХ ст. ; за ред. В. Г. Дончика. - Київ : Либідь, 1998. - С. 14.

Засенко 1968 - Засенко О. Осип Маковей / О. Засенко. - Київ : Дніпро, 1968.

Історія української літератури 2005 - Історія української літератури. Кінець XIX - початок XX ст. : у 2 кн. : підручник / За ред. проф. О. Д. Гнідан. Київ : Либідь, 2005. - Кн. 1. - 624 с.

Кузьменко 2013 - Кузьменко В. І. Літературний процес в Україні на початку XX ст. // Історія української літератури XX - поч. XXI ст. : навч. посіб. : у 3 т. / В. І. Кузьменко, О. О. Гарачковська, М. В. Кузьменко та ін.; за ред. В. І. Кузьменка. - Київ : Академвидав, 2013. - С. 10.

Маковей 1990 - Маковей О. С. Твори : В 2 т. - Т. 2 : Художня проза / Упоряд. та авт. приміт. О. В. Мишанич / Осип Маковей. - Київ : Дніпро, 1990. 537 c. 
Мельничук 1956 - Мельничук Ю. Осип Маковей (Життя і прозова творчість / Ю. Мельничук // Маковей О. Вибране. - Львів: Кн.-журн. вид-во, 1956.

Погребенник 1960 - Погребенник Ф. Осип Маковей (Критикобіографічний нарис) / Ф. Погребенник. - Київ : Держ. вид-во художньої літератури, 1960.

Погребенник 1990 - Погребенник Ф. П. Осип Маковей / Ф. П. Погребенник // Маковей О. С. Твори : В 2 т. - Т. 1 : Поетичні твори. Повісті / Авт. передм. Ф. П. Погребенник; упоряд. та авт. приміт. О. В. Мишанич / Осип Маковей. - Київ : Дніпро, 1990. - С. 5-24. 